\title{
1 - Introduction: making change happen - citizen action and national policy reform
}

\author{
JOHN GAVENTA AND ROSEMARY MCGEE ${ }^{1}$
}

How can ordinary citizens - and the organizations and movements with which they engage - make changes in national policies which affect their lives, and the lives of others around them? Under what conditions does citizen action contribute to more responsive states, pro-poor policies and greater social justice? What is needed to overcome setbacks, and to consolidate smaller victories into 'successful' change? These are the questions taken up by this book. Understanding the answers is important for a number of contemporary debates that cut across policy, activist and academic circles.

In international development debates, the challenge of building responsive and accountable states which in turn will work to alleviate poverty, protect rights and tackle social inequalities has been a focus of attention in recent years. Much of the debate centres on improving the institutions of government - state bureaucracies, parliaments and justice systems. Yet, as this book demonstrates, states are not built through institutions alone. Organized citizens also play a critical role, through articulating their concerns, mobilizing pressure for change and monitoring government performance.

For those concerned with citizen advocacy, in recent years there has been a great deal of attention on building global or transnational citizen action, as witnessed in significant citizen mobilizations such as the Make Poverty History campaign on aid, trade and debt in 2005, as well as the continuing Global Call to Action Against Poverty, the UN Millennium Campaign, and now campaigns on climate justice. Yet increasingly, activists in these campaigns are also turning their attention to the importance of national policy change, with the realization that unless there are changes at this level, international policies will have little traction.

Similarly, an explosion of work over the last decade has focused on citizen participation and citizen mobilization to strengthen the 'voice' of civil society actors in governance and development programmes. Much of this has been on the local level, or on forms of public 'consultation', 
which - while broadening participation - often lack real power to make a change. Recognition is mounting that policy change must scale up from the local to embrace the national as well, and that programmes for citizen participation must go beyond articulating voice to exerting real influence. How can this be done?

Drawing from eight case studies in which organized citizen action has contributed to significant national policy changes, this book will engage with, and we hope bring fresh insights to, these debates. Looking across these cases of change, we ask how and under what conditions they occurred, and what can be learned from 'successful' examples of citizen mobilizations changing national policy.

Each of the subsequent chapters in this volume attests to the power of people to make change happen. They fundamentally affirm that citizens can engage with states to create policy reforms which are important to the lives of poor people and for achieving social justice, but that intensive, long-term, organized collective action and coalition-building are required to do so. When this ensues, the results can be significant:

- In South Africa, the Treatment Action Campaign led to public recognition of HIV/AIDS as an issue, and to over sixty thousand people gaining access to publicly supplied antiretroviral medicines (Chapter 2).

- In the Philippines, the National Campaign for Land Reform secured the redistribution of half of the country's farmland to 3 million poor households, contributing to their economic rights and livelihoods (Chapter 3).

- In Mexico, a campaign to reduce maternal mortality put the issue of maternal healthcare on the national agenda in an unprecedented way, contributing to important changes in national budget priorities and health delivery mechanisms at the local level (Chapter 4).

- In Chile, an NGO-led campaign on child rights attained a new policy framework benefiting children, contributing to a decrease in child poverty (Chapter 5 ).

- In India, a grassroots-inspired campaign led to the passage of a strong National Right to Information law in 2005, and also provided impetus for further laws to enhance social security based upon new structures of public accountability (Chapter 6).

- In Brazil, the Right to the City campaign established a national framework for citizen participation in urban planning, critical to achieving housing and other social rights (Chapter 7).

- In Morocco, a women's social movement carried out a successful 
campaign for reform of the moudawana, the Islamic family law affecting women's rights (Chapter 8).

- In Turkey, a campaign for women's rights led to a new penal code with thirty-five amendments for the protection of sexual rights (Chapter 9).

Such policy changes, at best momentous and at least stepping stones towards future significant reforms, also constitute steps towards internationally recognized development goals, and social and economic rights. Several of these gains link directly to the donor-established Millennium Development Goals - for instance, those related to gender equality (Morocco and Turkey), maternal health (Mexico), combating HIV/AIDS (South Africa), and ending poverty and hunger (Philippines). Others represent the sixty-year-old struggle to realize basic social and economic rights enshrined in the 1948 UN Declaration of Human Rights, such as those advancing child rights in Chile, housing rights in Brazil or women's rights in Morocco and Turkey. Others still establish the preconditions necessary for realizing these economic and social rights - for instance, the right to information in India and popular participation in urban planning in Brazil. By gleaning lessons for how change happens from case studies such as these, we can build more successful movements and provide better-attuned support towards achieving these international goals for development, social justice and deeper democratic engagement.

\section{Project and case study background}

While these cases are both inspirational and instructive, they have inevitably been shaped by their own particular contexts. The eight countries from which the cases are drawn are largely classified as middleincome nations, notwithstanding the high levels of inequality and large numbers of poor people within them. ${ }^{2}$ Each has at least a modicum of democratic space, which is a prerequisite for citizen engagement on national policy issues, but is not a given everywhere. Each has a functioning state apparatus, another prerequisite for effective action on policy change, for without a functioning state there are few incentives to change its policies in the first place.

To a degree, these characteristics may limit the extent to which conclusions can be drawn for how change happens in other settings which lack these qualities. On the other hand, the fact that the successes arose in these contexts is an important finding in itself. In embarking on this project, we used our extensive networks to purposively seek 